\title{
Patterns of interrelation between perception and understanding of images and texts with different degree of blur
}

\author{
Oksana V. Zashchirinskaia ${ }^{1}$ \\ Published online: 29 July 2019 \\ (C) The Psychonomic Society, Inc. 2019
}

\begin{abstract}
The efficiency of information processing depends on a holistic and integrated process of understanding. Eye tracking helps us to study the peculiarities of the understanding of visually perceived stimuli. The purpose of this study was to identify and characterize the relationship between perception and understanding, on the example of images and texts with different degrees of blurring (visual complexity). The work involved 25 participants, ages 19 to 25 years. Methods include poll, recording eye movements (eye tracking), wavelet filtering of text and images, and content analysis. Stimuli were consistently presented on the screen included text stimuli (from 7 texts), episodes from Russian fairy tales, and images (from 8 comics total), each consisting of eight pictures, united by one complete plot. Visual stimuli were presented in order from the clearest to the most blurred image. The results of the study showed that the participants made more gaze fixations on plot-relevant details and characters. They reveal key details of images for a general understanding of the content. The willful regulation of cognitive processes allows distinguishing the main characters and keywords to recreate or anticipate the meaning of visually perceived information constructs while reading texts or pictures with a high degree of blur.
\end{abstract}

Keywords Visual perception · Eye tracking $\cdot$ Content understanding $\cdot$ Cognitive processes $\cdot$ Content analysis

Not many published works reveal new approaches to understanding methods, and few works are devoted to the relationship of understanding with perception, despite their explicit connection (Clark, 1977; Bodalev, 2012; Matyushkina, 1965; Brudnyy et al., 1991; Doblayev, 1982; Zinchenko, 1997). At the same time, some researchers have shown the influence of perception on understanding (Znakov, 1991; Znakov, 2002; Belobrykina, 2016; Znakov, 2013; Kvasyuk, 2010; Kostyuk, 1988). Levkova (2009), for example, considers perception and understanding as being different sides of the same phenomenon: Perception reflects the process, and understanding is the result. This conclusion was formulated in the context of studying the process of reading. It was revealed that reading text cannot take place without perceiving, and understanding what has been read. To achieve this, a person is required to launch mental activity (Levkova, 2009).

Oksana V. Zashchirinskaia

zaoks@mail.ru

1 Department of Pedagogics and Pedagogical Psychology, Saint-Petersburg State University, 199034, 7/9 Universitetskaya Emb, Saint-Petersburg, Russian Federation
The definition of the term "understanding" is defined by Dunker through the concept of gestalt, which refers to the visuospatial form of perceived objects and which is key in studying the processes of perception and structuring of human sensations: "Understanding something means acquiring a gestalt or seeing its functional place in the gestalt" ( $p$. 33)(Brudnyy, 2002; Leontyev, 2005). Gelmgolts \& Maklakov (2002) noted, that "in acts of perception the unequivocal understanding is carried out.... Perceptual activity itself is one of the forms of cognitive activity, one of the forms of understanding" (p. 58).

Being a unique phenomenon, understanding is a holistic integrated process in which the differentiation of individual cognitive functions is extremely conditional, since it is not only difficult to consider them separately from each otherwhere, for example, perception ends and thinking, speech, and imagination begins - but it is almost impossible to fix them by psychological methods (Zashchirinskaia et al., 2015a; Solso, 2006; Keltner \& Haidt, 1999; Pelc et al., 2006; Bransford \& McCarroll, 1974; Portnova, 2016; Shinysherova et al. 2018; Rehbein \& Saalmann, 2009). With a high degree of accuracy, the objective picture of the features of the participant's perception, which is significant for revealing the features of understanding, allows us to fix instrumental methods 
of measurement. The mutual determination of understanding and perception noted by individual scientists determined the direction of our research, the purpose of which was to identify and characterize the interrelationships of perception and understanding, defined by the example of images and texts with varying degrees of blurring of the perceived stimulus material.

\section{Method}

\section{Subjects}

The study involved 25 students, ages 19 to 25 years, from the Faculty of Psychology of Saint-Petersburg State University (1-4 courses). Of these, six were males and 19 were females. The research revealed descriptive characteristics that act as conditional standards for the specific understanding of images and texts with different degrees of blurring of the perceived stimulus material. This is the definition of conditional standards for the relationship between perception and understanding (on the sample of the student subjects).

\section{Methodology}

To identify patterns of interconnection between visual perception and understanding of texts and plot pictures, the following methods were used.

\section{The survey method}

I used a questionnaire that aimed to identify the specifics of respondents' understanding of images and texts. The questionnaire contained multiple-choice questions (where participants had to choose one of the suggested answers) and openended questions (which required a free form of response). Participants were asked to write a brief summary of what they saw (for each stimulus) and describe heroes, their actions, and plot. Also, each participant estimated the degree of his or her understanding of the texts and comics on a 6-point scale $(0=I$ did not understand anything; $6=$ I understood everything). In addition, the subjects described the elements in the pictures and texts that attracted the most attention, which allowed us to determine their areas of interest and compare how those areas coincided with the fixed attention zones identified by recording their eye movements.

\section{Eye tracking}

Method of distant eye-movements recording We conducted the study using the EyeTribe eye tracker with Ogama software. We used heatmaps for illustrations and calculated statistics for selected areas of interest.
Method of wavelet filtering of texts and images The stimulus material was verbally and nonverbally presented to participants using two Asus notebooks, with a screen resolution of $1,680 \times 1,050$. As examples of verbal patterns, text images were used (eight texts in the preliminary study, three in the study of high school students) consisting of fragments of Russian folk tales in black letters on a gray background (see Fig. 1a). Fragments on average contained 700 characters, including spaces and punctuation marks. As nonverbal patterns, the comics of Herluf Bidstrup, the Danish caricaturist, were used (seven "elements" of the plot were used in the preliminary study - two in the high school students study; data on schoolchildren are not represented at all; see Fig. 1b).

The images and texts were processed by wavelet filtration. The term "wavelet" was first encountered in the works of Grossmann and Morlet (1984, pp. 723-736), in which they tried to analyze and carry out digital processing of the properties of seismic and acoustic signals. Thanks to the wavelet transformation of onedimensional signals, their analysis can be performed in two spaces at once: a two-dimensional sweep is performed, in which the frequency and coordinates act as independent variables.

With the help of wavelets localized in time or frequency, the signals and functions are represented in the form of wavelet superposition's at different levels of signal decomposition. Currently, wavelets are used not only for processing and analyzing various signals but also for processing, data filtering, and for compression and image processing (Bilynsky et al., 2017). All images were preliminarily subjected to wavelet filtration by convolution with a difference of Gaussians (DoG) function, a wavelet that is the difference of two twodimensional Gaussian functions with different half widths ${ }^{1}$ :

$f(x, y, \sigma)=\frac{1}{2 \pi \sigma^{2}} \exp \left(-\left(x^{2}+y^{2}\right) /\left(2 \sigma^{2}\right)\right)-\frac{1}{2 \pi N^{2} \sigma^{2}} \exp \left(-\left(x^{2}+y^{2}\right) /\left(2 N^{2} \sigma^{2}\right)\right)$

where $\sigma$ is the standard deviation and $N$ is the scale factor - in our case, equal to 2 .

According to Marr (1982), the best model for them is image processing by a set of $\nabla^{2} \mathrm{G}$ filters, where $\nabla^{2}$ is the Laplace operator $\left(\mathrm{d}^{2} / \mathrm{d} x^{2}+\mathrm{d}^{2} / \mathrm{d} y^{2}\right)$, and $\mathrm{G}$ is the Gaussian function. Processing the image with the $\nabla^{2} \mathrm{G}$ filter allows you to select sharp brightness changes corresponding to the boundaries of objects on the image, and, by changing the half width of the

\footnotetext{
${ }^{1}$ There was a miserly old man. He had two sons, and a lot of money. Once he heard death, he locked himself in his spacious cottage. What to do? He must preserve his wealth. The old man sat on a big chest and began to swallow gold coins and eat banknotes. He hurried, and ate a lot of money. But he did not make it. So his life ended. After a while, his sons came. They saw what had happened. They put their dead father under the holy icons and called the clerk to read the psalter. Suddenly, at midnight, an impure person appears in the image of a man. He raised the dead old man on his shoulder and said: "Hold, clerk, his robe!" and he began to shake the old man: "The money is yours, and the bag is mine!" He took the dead old man, put him in a bag, and became invisible.
} 
Жил был скупой скряга, старик. Он имел двух сыновей и множество денег. Послышал смерть, заперся один в своей просторной избе. Что же делать? Надо же сохранить свои богатства. Сел старик на большой сундук, начал глотать золотые деньги и есть ассигнации. Торопился, много съел. Только всё-таки не выдержал, так и покончил свою жизнь. Спустя немного времени пришли сыновья, увидели они, что случилось. Положили сыновья своего мёртвого отца под святые иконы и позвали дьячка читать псалтырь. Вдруг в самую полночь является в образе человека нечистый. Он поднял мёртвого старика на плечо и сказал: «Держи, дьячок, полу!». И начал сильно трясти старика: «Деньги твои, а мешок мой!». Взял он мёртвого старика, положил в мешок и невидим стал.

a

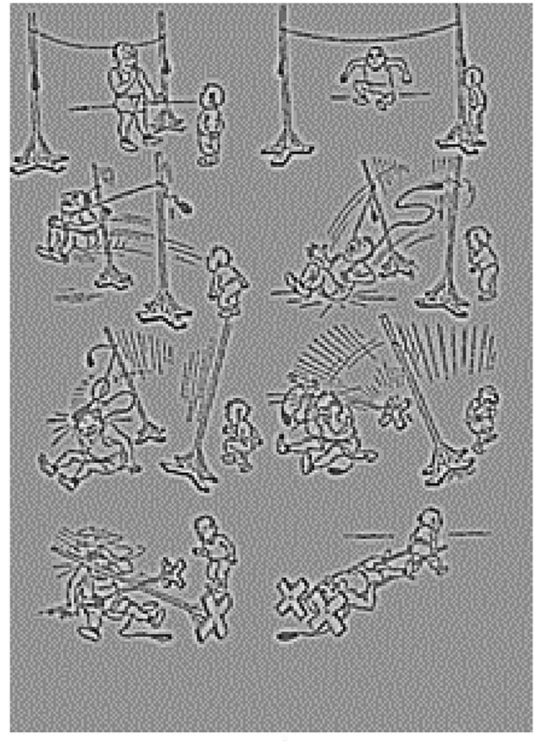

b

Fig. 1 Examples of incentives. a Verbal stimulus (Russian folk tale "Death of the Mean"). b Nonverbal stimulus (Bidstrup comic "Jump in Height"). Visual filter was applied on both stimuli with a maximum frequency characteristic position of five cycles/deg during the test

Gaussian, it is possible to allocate borders at different scale levels. Marr proposed the representation of $\nabla^{2} \mathrm{G}$ filters using the difference of two Gaussian, that is, the DoG function. At present, this technique is widely used in technical vision (Buyakas, 2009).

An analogue of DoG functions for the visual analyzer are receptive fields with circular symmetry, which are typical for the retina and lateral geniculate body. The optimal stimulus for such cells (i.e., image), which reacts only a group of neurons with similar in frequency response receptive fields, is an image whose spatial-frequency spectrum lies within the frequency band to which the given group of cells reacts. These requirements are met either by the DoG functions themselves or by images digitally filtered using them. By changing the value of the standard deviation $\sigma$ in Equation 1, it is possible to shift the position of the maximum of the frequency characteristic of the filter, which allows us to distinguish different spatial- frequency ranges. In the present study, filters with the following positions of the maximum frequency response were used to process images with comics: $5.0 ; 3.75 ; 2.81 ; 2.11 ; 1.58$; $1.19 ; 0.89 ; 0.667 \mathrm{cycle} / \mathrm{deg}$. The ratio of adjacent frequencies is 0.75 . To process images with texts, another set of filters was used: $5.0 ; 4.0 ; 3.2 ; 2.56 ; 2.05 ; 1.64 ; 1.31$ cycle/degree, with the ratio of adjacent frequencies equal to 0.8 . It is important to emphasize that for texts and comics, frequencies with variable pitch were chosen. Nevertheless, in both cases, the first filter gave an image that shows all the details, and the last one was completely blurry, in which it is impossible to recognize any objects (see Fig. 2).

\section{The method of content analysis}

This is a method of qualitative and quantitative analysis of the content of the text, consisting in the systematic fixation and
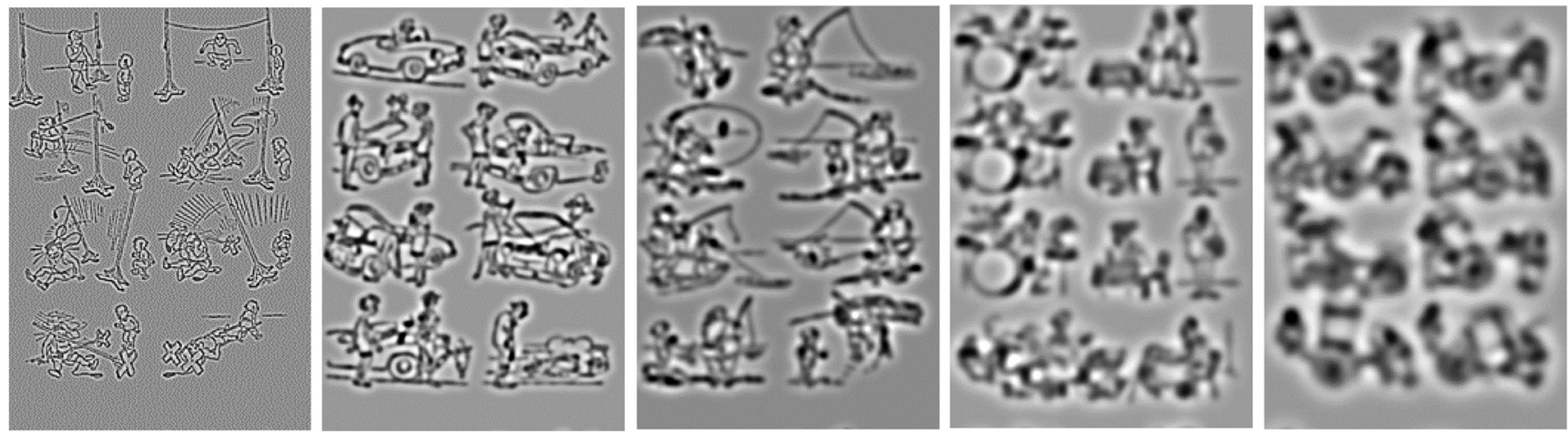

Fig. 2 Examples of filtering nonverbal stimuli with specified positions of the maximum frequency response 
quantification (calculation) of certain units of the content of the text under investigation (Makarov, 2001; Lamminpiya et al., 2015; Denham, 2006; Rumelhart, 1977).

Content analysis allows us to convert qualitative information into quantitative indicators and distribute them according to predefined (preset) categories. The result of a quantitative analysis of the content of the data can be parameters such as the frequency of occurrence of certain semantic concepts in the text and the degree of expression of their interrelationships. When using this method, it is possible to extract (extract, define) categories that combine words according to a certain feature. Reliability of content analysis is provided by peer review, when several people who do not know the essence of the hypothesis being tested assign the concept to a category. After the independent classification by all experts of the units of analysis, a joint discussion is held on the adequacy of each designated category and its harmonization.

This method was used to identify features of the understanding and interest of the subjects to the presented texts and comics. Based on the analysis of the seven participant's answers by experts, specific evaluation categories were formulated (through generalization). As a result of the established classification, each response of the subject was characterized from the point of view of the presence of indicators and semantic units in it, allowing the statement to be assigned to a certain evaluation category. At the final stage, the experts calculated the percentage of subjects surveyed, in which the semantic units of each class they established were observed.

\section{Mathematical and statistical methods of data processing}

Statistical processing of data was carried out using the IBM SPSS Statistics program. To study the relationships between individual parameters, the Spearman rank correlation coefficient was used for varying degrees of blurring. To compare the indices of understanding and oculomotor reactions in texts and comics, a criterion of Wilcoxon's significant grades was used within each group. In order to identify statistically significant differences between groups, Sheffé's multiple comparison method (based on the variance analysis) was used for the given indicators. When calculating the frequency of occurrence of respondents' answers, the Pearson chi-square test was used.

\section{Procedure}

The procedure was carried out according to the following algorithm: on the monitor screen, participants consistently demonstrated verbal and nonverbal patterns in the form of texts and pictures in the order from the most clear to the most diffuse. The study used 15 stimuli (seven texts and eight images). The distance from the subject's eyes to the monitor, on which test images with texts and comics were presented, was $60 \mathrm{~cm}$. The procedure of the investigation was carried out on an individual basis. After viewing each stimulus, the participants were asked to fill out a short questionnaire aimed at revealing the features of understanding the texts and comics presented to each of them. In cases where respondents could not (for certain reasons) independently fill out the questionnaire, an oral questionnaire was used, which enabled them to receive the most comprehensive and meaningful answers using the specification technique.

In the course of the study, the participants were given the following instruction: "Now, comics will be presented on the monitor screen (there will be two), and then texts (three). Your task: Try to understand the meaning of images and texts. All incentives are blurred and will appear in order from clear to less clear, when it will be difficult to recognize. By time you are not limited, just tell me when you are ready. While viewing pictures or reading texts, eye movements will be recorded with this device (pointing to the eye tracker). Therefore, it is very important to look at the screen at all times and not be distracted, otherwise the device will not be able to fix its gaze. After viewing each comics/text, you will need to fill out a short questionnaire, and then we will proceed to view the next stimulus. Please look at the questions. Do you understand everything?"

\section{Results}

In the course of the pilot study, it was possible to identify at what level of the erosion of the stimulus image the participants had difficulty in recognizing the materials, as well as compare the understanding of the subjects of the texts and comics at different degrees of their visual complexity. The mean values of understanding by sample were calculated. It was found that participants had significant difficulties in understanding texts after the fifth stimulus, and in the understanding images after the third (see Fig. 3).

In the pilot study, the participants were offered images (comics) that had eight degrees of blurring for viewing. Each comic contained eight elements of the plot.

According to the pilot-study data, with well-viewed images of the comic, the duration of the fixation is related to the recognition of the person depicted. It was important for participants to understand immediately who the main 

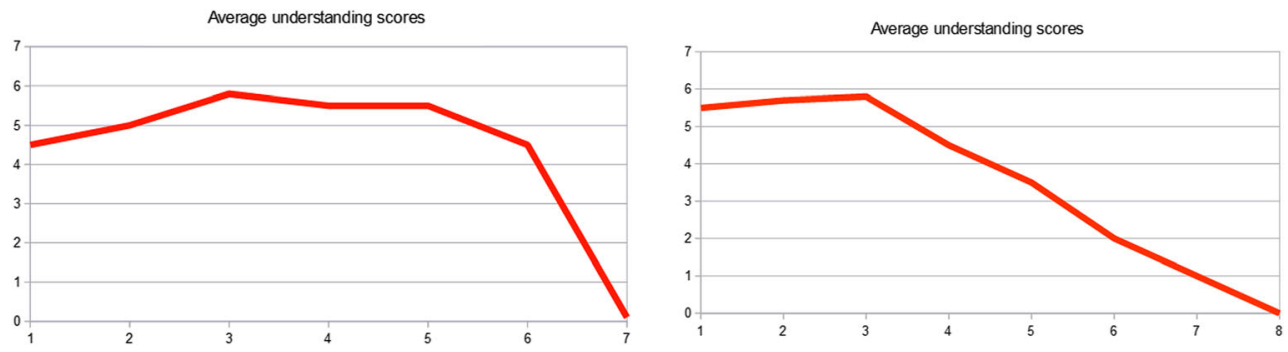

Fig. 3 Results of the distribution of data on the parameter of understanding texts (left) and comics (right) by the participants

character is and what his actions are, leading to the final result. It should be noted that the participants focused attention first on figures that are meaningful for understanding, which in turn can indicate the selectivity of perception. It is revealed that they deliberately ignore the intermediate results when viewing the images (see Fig. 4a).

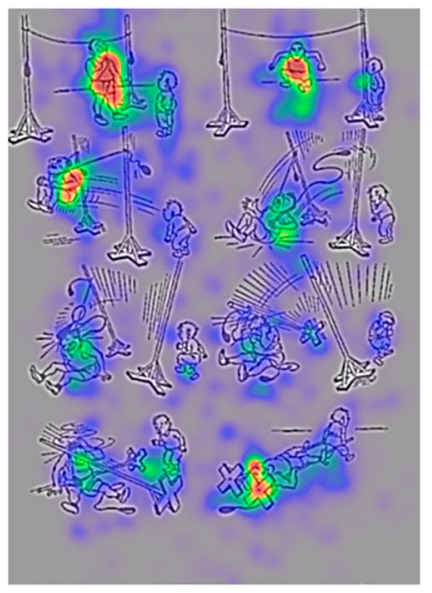

a

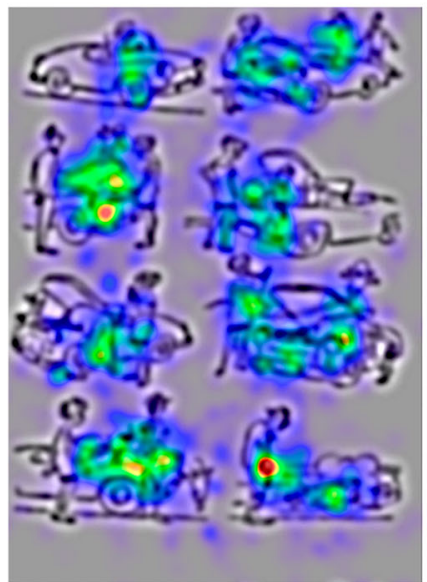

e

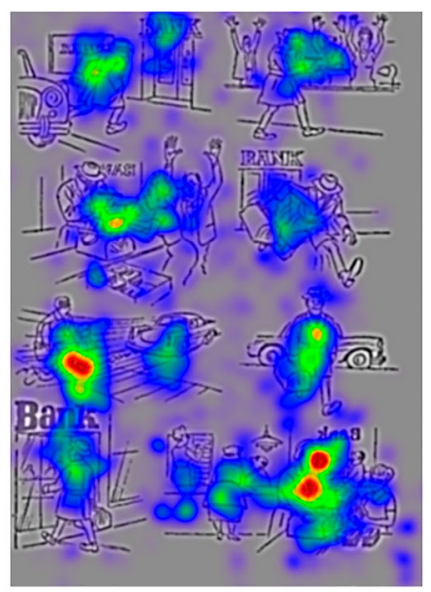

b

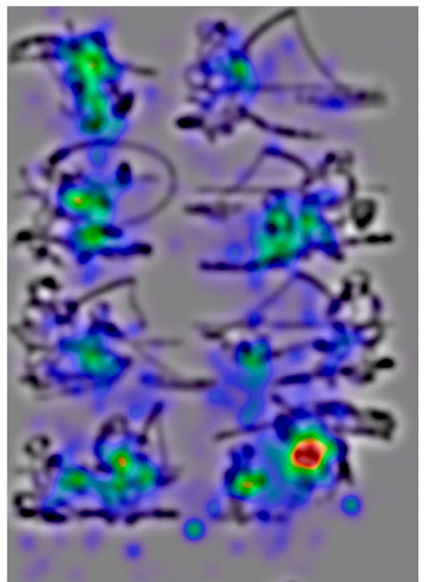

$f$

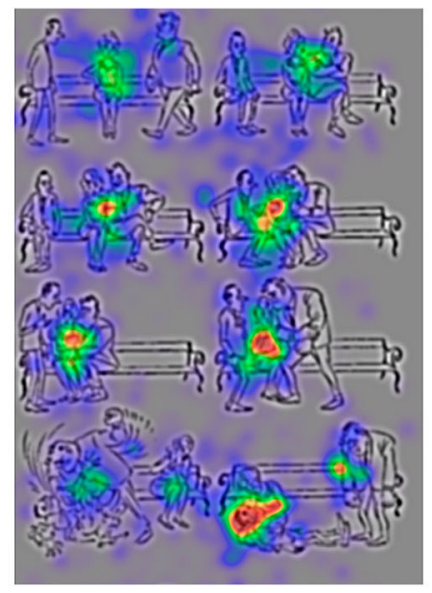

C

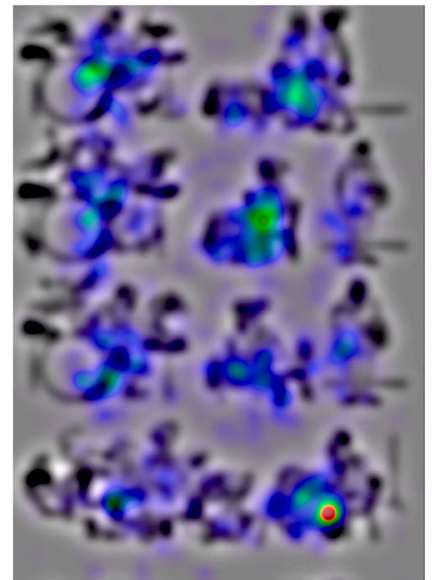

$\mathrm{h}$

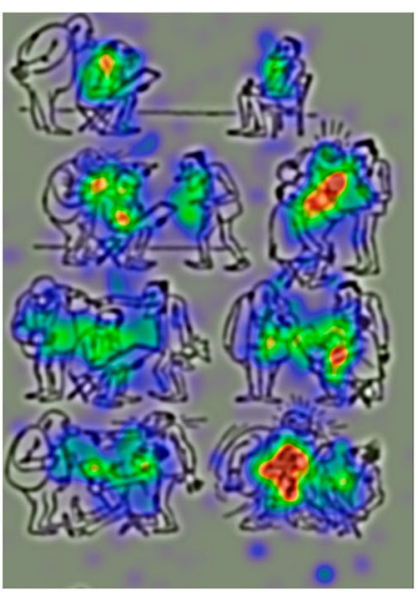

d

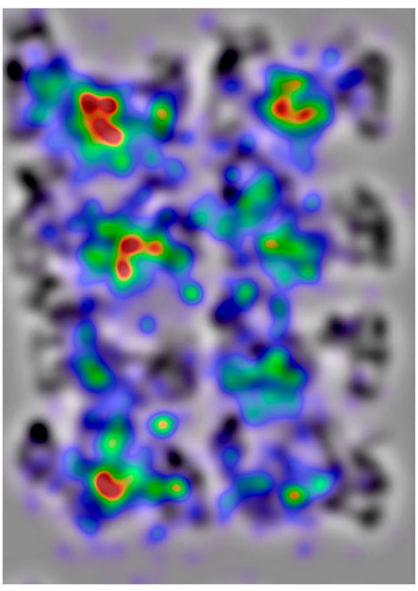

i
Fig. 4 Images with different degrees of blur. a Comics "Jump in Height" (first degree blur). b Comics "Banking Operations" (second degree blur). c Comics "Winner" (third degree blur). d Comics "Caricature" (fourth degree blur). e Comics "Cupid Miscalculated" (fifth degree blur). f
With the second degree of blurring, a tendency apin a more careful examination of not only the standing the plot. With these details, the dynamics of the entire plot and the final result are connected (see Fig. $4 b)$.
Comics "Fishing" (sixth degree blur). g Comics "Jazzbandist's Wife" (seventh degree blur). h Comics "Instant Photography" (eighth degree of blurring) 
With an increasing degree of blurring (third degree), the participants immediately concentrate their attention and determine the main subject whose behavior affects the dynamics of the entire plot in the pictures. In this case, a complete image of a person is perceived, and not individual details of the image. When assessing the result, and for the final conclusion in the analysis of the image, the participants have longer fixations on those characters that contributed to the end of the situation. Their actions in the analysis of the incident become a priority in the visual perception of the image (see Fig. 4c).

With a further increase in the degree of blurring (fourth degree), the indicated features of the picture are preserved. This increases the length of fixations on the details of the image of people, which are identified as being the most significant for a common understanding of the series of images (see Fig. 4d).

When analyzing the results of comics with the fifth degree of blurring, the duration of fixations as a whole increasestheir range (number) increases when each individual picture is viewed (see Fig. 4e).

When looking at comics of the sixth and seventh degrees of blurring, the previously revealed tendency is also preserved: for understanding the image as a whole, the participants testify to the last (eighth) picture reflecting the final result of the characters' actions in the presented plot (see Fig. $4 \mathrm{f}-\mathrm{g}$ ).

With the eighth degree of blurring, when it is almost impossible to determine what is depicted in the pictures, the participants begin to focus on the first fragments (details) of the image, but gradually their recognition efforts are reduced. The trend found at previous degrees of blurring, when participants tried to focus on the last picture and draw a final conclusion about the situation, is violated. The cognitive strategy of the participants in this case differs by an attempt to slowly and differentially view and strive to understand the detail of the image (see Fig. 4h).

An analysis of the empirical data of reading the texts (7) with varying degrees of blurring showed that the participants are also characterized by an emphasis on the main characters, and, to a greater extent, at higher levels of blurring of the stimulus material (see Fig. 5d).

At the first three levels of text blurring, there is a tendency to consider its ending in order to understand the meaning of the entire text (Fig. 5a-c). Starting with the fourth level of blurring, this trend disappears. At the sixth level of blurring, participants' strong-willed efforts are preserved in the reading: They fix attention on certain words, trying to read something, and the number of fixations and the length of the text viewing increases. However, when reading the last text, which is not possible due to a strong blurring of the stimulus, participants' efforts to recognize the text are reduced, which is reflected in a reduction in the number of fixations and the time for viewing the stimulus ${ }^{2,3,4,5}$.

On the basis of statistical data processing, the average assessment of participants' understanding of texts is reduced from 5.64 to 4 points (or this is the average number of incentives). When viewing comics, the average values of the degree of understanding are reduced after the third stimulus (from 5.56 to 4.44 points).

Figure 6 shows the mean values of understanding by the participants of each stimulus.

It should be noted that despite the low degree of blurring, the average score of understanding the first text and comics is lower than with more blurred stimuli (4.72 and 5.28, respectively). Such results might be caused by the novelty of the materials presented and the individual characteristics of the participants, including the specificity of their perception (Vygotskiy \& Davydov, 1982; Zhinkin, 1964; Zashchirinskaia et al., 2015b).

\footnotetext{
2 There was a miserly old man. He had two sons, and a lot of money. Once he heard death, he locked himself in his spacious cottage. What to do? He must preserve his wealth. The old man sat on a big chest and began to swallow gold coins and eat banknotes. He hurried, and ate a lot of money. But he did not make it. So his life ended. After a while, his sons came. They saw what had happened. They put their dead father under the holy icons and called the clerk to read the psalter. Suddenly, at midnight, an impure person appears in the image of a man. He raised the dead old man on his shoulder and said: "Hold, clerk, his robe!" and he began to shake the old man: "The money is yours, and the bag is mine!" He took the dead old man, put him in a bag, and became invisible.

${ }^{3}$ There was a peasant who had two sons, and suddenly, he died. The sons grieved for a long time, but they had to live on. The brothers conceived to marry. The older brother married a very poor girl, while the younger brother chose a rich bride. They lived together in their father's house. They lived together, but did not share. Their young wives began to quarrel with each other and to argue. One says: "I am married to the older brother; the top is mine!" The other shouts in response: "No, the top is mine! I am richer than you!" The brothers watched, listened, and were perplexed. However, they see that their wives cannot get along with each other. The sons divided all their father's property equally and went their separate ways. The elder brother had children born each year, but the household got worse and worse.

${ }^{4}$ Once upon a time there was a goat, and she had seven kids. Six of them were white, and the seventh goat was black. They lived together in a small, beautiful house, and they loved each other very much. One day the mom decided to go to the market and said to the children: "Wait for me at home, kids, and do not open the door for anyone. A gray wolf wanders in our forest. His paws are huge, his claws are sharp, and his voice is rough and angry! If you open the door, he will eat you!" She had just left the house, and the wolf was right there. He silently crept up to the door and howled. The kids were frightened by the wolfs' voice, and so they hid under the bench and the stove. They sat trembling without being seen. The wolf stood at the door, hesitated, and decided to leave. The kids do not open the door for him. But hunger torments the wolf. He will come up with something else, and deceive the kids.

${ }^{5}$ Once upon a time, there lived old man and woman. They had a granddaughter, Tanya. Once they sat at their home and saw a shepherd driving a herd of cows. All kinds of cows: red, motley, black, and white. And a bull near the cow—a small, black one. He jumped all around, a very good bull—a zinger. So Tanya says: "I wish we would have such a calf." Grandfather thought and thought, and finally decided: "I'll get a calf for Tanya." Where, he did not mentioned. He thought about it and decided to go to the market in search of a bull. But it was a challenge to find a good calf. Different animals were offered, but grandfather did not like a single one. "I wanted to buy a calf to please Tanya. I wanted a nice black bull.”
} 


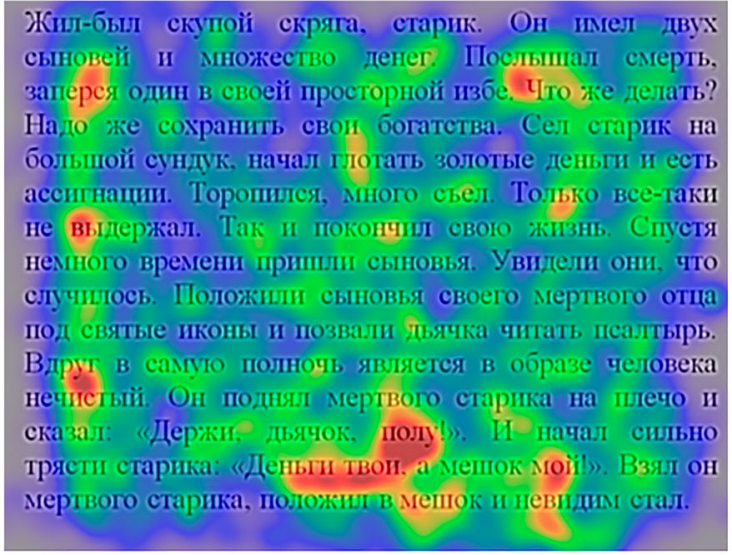

\section{a}

Жина-была коза. И било у нее семеро козлят.

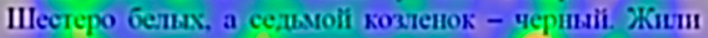
они ,ружно ит весело в малтенком, краством домике и очень лобнш друт друга. Вот собратась однажды коза на базар и товоріт детям: “Жлите меня дома, козлята, и никому не открыва丿іне дверь. Бродит в натем лесу серніi волк. Латы у него огромине, когти острые, а голос грубый и злой Еелі огроете, он вас сьест!. Тодько она вышта из дома, а вотк тут как тут. Тіпо-тихо подкралея к двери и завьц. Испугались козляга водчьего полоса, попрятались все под лавки и

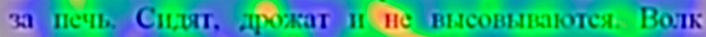

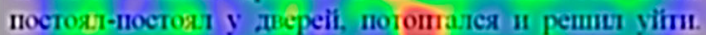
Не открываю ему дерь козияла. Но голод мучает. Надо что-то другое прндумать, обчанут, козля.

\section{C}

Жил да был мужик, прнжин двух сыновей и внезапно помер. Горевали долго сыновья, но жить надо далыше. Вот задумали братья жениться. Старшиіи брат взял в жены совсем бедную девушку, а младший брат выбрал богатую невесту. Сталі все вместе жить в отцовском доме. Живут вместе, но не делятея. Вот начали их молодые жены меж собої ссоритьея да вздорить. Одна говорит: «Я за старшим братом замужем; мой верх должон быть!». А другая ей в ответ кричіт: «Нет, мой верх! Я богаче теб̆я!). Братья смотреліи, слушали и недоумевали. Однако видят, что жены никак друг с другом не ладит. Тогда разделити сыновья все отцовское добро поровну и разошлись. У старшего брата что -и год. то дети рождаюося, а хозяйство все плоше да хуже пдет.

\section{b}

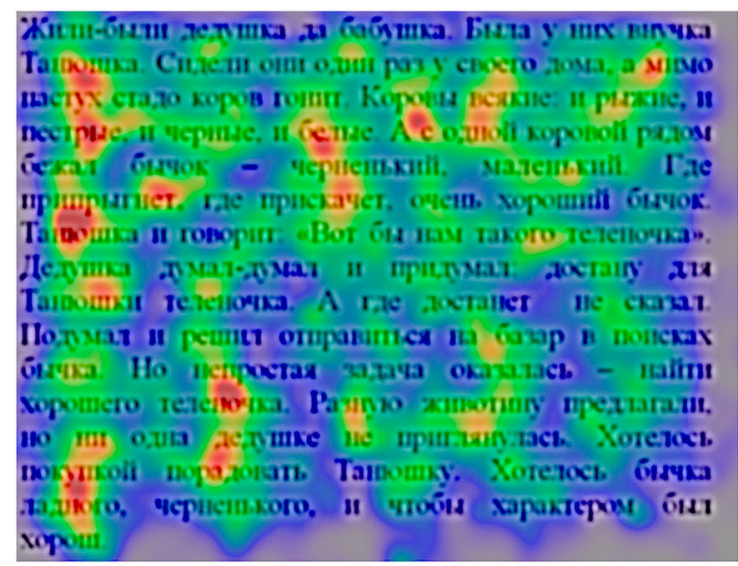

d

Fig. 5 Examples of blurred texts. a First degree of blurring. b Second degree of blurring. $\mathbf{c}$ Third degree of blurring. $\mathbf{d}$ Fourth degree of blurring

Seeing the text or comics for the first time, and having no previous experience in solving such tasks, participants might become confused, which, accordingly, could raise their level of anxiety, which, undoubtedly, will affect the evaluation of understanding. Subsequently, participants adapt to similar tasks, and their subjective assessments of the understanding of what they see increase (Zinchenko, 1998; Kostyuk, 1959; Leontyev, 2005; Lidin, 2004). Hence, in our opinion, the effect of learning
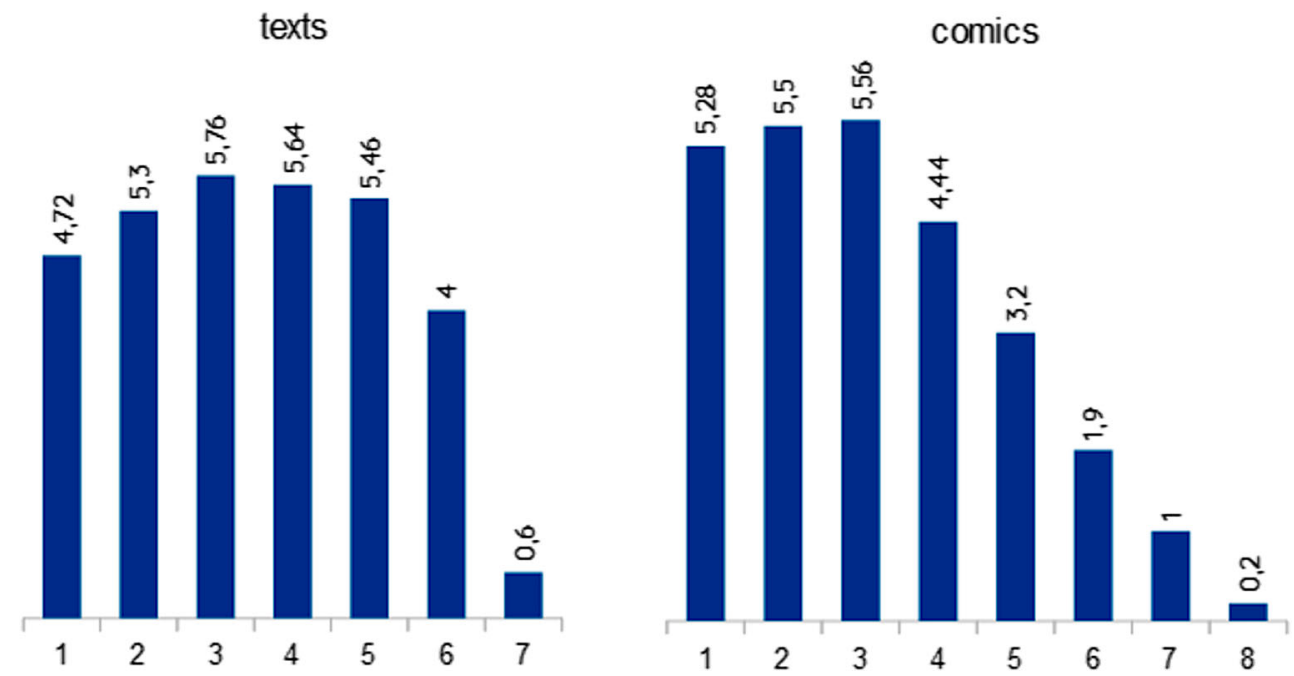

Fig. 6 Mean values of understanding scores. Diagram of the distribution of indicators of the average values of subjective assessments of participants and their understanding of texts and comics at different degrees of visual complexity 
Table 1 Indicators of the percentage distribution of data on the parameter of the manifestation of the interest of the participants to texts

Stimulus Response categories

\begin{tabular}{|c|c|c|c|c|c|c|c|c|c|}
\hline & $\begin{array}{l}\text { A certain } \\
\text { detail / hero / } \\
\text { action / in } \\
\text { images }\end{array}$ & $\begin{array}{l}\text { Making } \\
\text { the } \\
\text { whole } \\
\text { story }\end{array}$ & $\begin{array}{l}\text { Emotional response } \\
\text { The meaning of the } \\
\text { comics, the } \\
\text { conclusion drawn }\end{array}$ & $\begin{array}{l}\text { The meaning } \\
\text { of the comics, } \\
\text { the conclusion } \\
\text { drawn }\end{array}$ & $\begin{array}{l}\text { Sensation } \\
\text { after } \\
\text { viewing }\end{array}$ & $\begin{array}{l}\text { Boring, } \\
\text { indifferent, } \\
\text { there is } \\
\text { nothing new }\end{array}$ & $\begin{array}{l}\text { Appearance } \\
\text { of unpleasant/ } \\
\text { negative } \\
\text { emotions }\end{array}$ & $\begin{array}{l}\text { Inadequacy in the } \\
\text { plot, } \\
\text { misunderstanding }\end{array}$ & $\begin{array}{l}\text { External } \\
\text { factors } \\
\text { affecting } \\
\text { perception }\end{array}$ \\
\hline Text 1 & $36 \%$ & $40 \%$ & $16 \%$ & $0 \%$ & $0 \%$ & $16 \%$ & $8 \%$ & $0 \%$ & $0 \%$ \\
\hline Text 2 & $12 \%$ & $28 \%$ & $12 \%$ & $20 \%$ & $0 \%$ & $28 \%$ & $0 \%$ & $12 \%$ & $0 \%$ \\
\hline Text 3 & $32 \%$ & $4 \%$ & $12 \%$ & $4 \%$ & $0 \%$ & $44 \%$ & $0 \%$ & $8 \%$ & $0 \%$ \\
\hline Text 4 & $32 \%$ & $20 \%$ & $16 \%$ & $0 \%$ & $0 \%$ & $24 \%$ & $4 \%$ & $12 \%$ & $0 \%$ \\
\hline Text 5 & $32 \%$ & $0 \%$ & $16 \%$ & $4 \%$ & $4 \%$ & $40 \%$ & $4 \%$ & $4 \%$ & $4 \%$ \\
\hline Text 6 & $44 \%$ & $8 \%$ & $4 \%$ & $12 \%$ & $12 \%$ & $12 \%$ & $8 \%$ & $4 \%$ & $8 \%$ \\
\hline Text 7 & $8 \%$ & $0 \%$ & $4 \%$ & $0 \%$ & $0 \%$ & $0 \%$ & $0 \%$ & $0 \%$ & $92 \%$ \\
\hline
\end{tabular}

reveals itself, in which a change in action occurs as a result of the acquisition of a certain experience (Torndayk \& Uotson, 1998; Menchinskaya, 2004; Nalchadzhyan, 2009; Rishar, 1998; Rubinshteyn, 1958). However, this effect is manifested only as long as the degree of blurring does not prevent the subject from deconstructing the text or comics. At the same time, participants find it more difficult to understand the incentives that lie in the area of maximum blurring.

\section{Discussion}

In the course of the experiment, after completing the review of each image and text, the participant was asked to fill out a short questionnaire aimed at identifying the features of understanding. In particular, the participants had to assess the understanding of each stimulus on a 6-point scale, briefly state the meaning of what they saw, and also assess how interesting the texts and comics were.

Participants' answers reflecting their interest in texts and comics were processed using the nonparametric chisquare Pearson criterion. The participants had to answer yes or no to the question of whether they found something interesting in the texts and comics. After looking at comics with first-degree blurring, $84 \%$ of the participants answered in the affirmative. Comics with third-degree blurring were noted as being interesting by only $56 \%$ of participants. The first degree of blurred text was interesting to $76 \%$ of participants, the third degree, $48 \%$, and the fifth, $56 \%$.

Table 2 Indicators of percentage distribution of data on the parameter of the manifestation of interest of the participants to comics

\begin{tabular}{|c|c|c|c|c|c|c|c|c|c|}
\hline \multirow[t]{2}{*}{ Stimulus } & \multicolumn{9}{|c|}{ Response categories } \\
\hline & $\begin{array}{l}\text { A certain } \\
\text { detail / hero / } \\
\text { action / in } \\
\text { images }\end{array}$ & $\begin{array}{l}\text { Making } \\
\text { the } \\
\text { whole } \\
\text { story }\end{array}$ & $\begin{array}{l}\text { Emotional response } \\
\text { The meaning of the } \\
\text { comics, the } \\
\text { conclusion drawn }\end{array}$ & $\begin{array}{l}\text { The meaning } \\
\text { of the comics, } \\
\text { the conclusion } \\
\text { drawn }\end{array}$ & $\begin{array}{l}\text { Sensation } \\
\text { after } \\
\text { viewing }\end{array}$ & $\begin{array}{l}\text { Boring, } \\
\text { indifferent, } \\
\text { there is } \\
\text { nothing new }\end{array}$ & $\begin{array}{l}\text { Appearance } \\
\text { of unpleasant } \\
\text { / negative } \\
\text { emotions }\end{array}$ & $\begin{array}{l}\text { Inadequacy in the } \\
\text { plot, } \\
\text { misunderstanding }\end{array}$ & $\begin{array}{l}\text { External } \\
\text { factors } \\
\text { affecting } \\
\text { perception }\end{array}$ \\
\hline $\begin{array}{c}\text { Comics } \\
1\end{array}$ & $40 \%$ & $8 \%$ & $28 \%$ & $16 \%$ & $0 \%$ & $8 \%$ & $4 \%$ & $12 \%$ & $0 \%$ \\
\hline $\begin{array}{c}\text { Comics } \\
2\end{array}$ & $28 \%$ & $8 \%$ & $36 \%$ & $8 \%$ & $0 \%$ & $12 \%$ & $4 \%$ & $16 \%$ & $0 \%$ \\
\hline $\begin{array}{c}\text { Comics } \\
3\end{array}$ & $20 \%$ & $12 \%$ & $16 \%$ & $8 \%$ & $0 \%$ & $44 \%$ & $0 \%$ & $4 \%$ & $0 \%$ \\
\hline $\begin{array}{c}\text { Comics } \\
4\end{array}$ & $12 \%$ & $12 \%$ & $20 \%$ & $8 \%$ & $0 \%$ & $20 \%$ & $8 \%$ & $8 \%$ & $16 \%$ \\
\hline $\begin{array}{c}\text { Comics } \\
5\end{array}$ & $16 \%$ & $0 \%$ & $4 \%$ & $4 \%$ & $4 \%$ & $32 \%$ & $4 \%$ & $8 \%$ & $32 \%$ \\
\hline $\begin{array}{c}\text { Comics } \\
6\end{array}$ & $20 \%$ & $0 \%$ & $0 \%$ & $8 \%$ & $0 \%$ & $4 \%$ & $0 \%$ & $4 \%$ & $64 \%$ \\
\hline $\begin{array}{c}\text { Comics } \\
7\end{array}$ & $20 \%$ & $0 \%$ & $0 \%$ & $0 \%$ & $0 \%$ & $0 \%$ & $0 \%$ & $4 \%$ & $76 \%$ \\
\hline $\begin{array}{c}\text { Comics } \\
8\end{array}$ & $8 \%$ & $0 \%$ & $8 \%$ & $0 \%$ & $0 \%$ & $0 \%$ & $0 \%$ & $4 \%$ & $80 \%$ \\
\hline
\end{tabular}


According to the conditions of the experiment, the participants needed to assess not only how interesting comic books and texts were but also to briefly argue their position, which enabled them to determine informatively loaded categories on the basis of the content analysis of the answers (Myasishchev, 1995; Mey, 2001; Epshteyn, 2007; Bamberg, 2011). The obtained results confirm the tendency of participants to identify key figures that are significant for understanding the details and actions of the main characters on the presented subjects (Belobrykina \& Vorobyova, 2015; Gruschka, 2011; Bahtin, 1986; Matsumoto, 2003; Saarni, 1999).

This is confirmed by the statements of participants whose content contained words directly related to the main characters and their actions - for example: "boy" (56\% of the surveyed), "adult" (64\%), "child" (32\%), "failed leap" (84\%), "robber" (100\%), "bank robbery" (92\%), "depositing stolen money in another bank" (88\%) "girl on the bench" (88\%), "attempts get acquainted" (64\%), "fight" (96\%), "artist" (80\%), "first/second man" (80\%), and so forth.

Tables 1 and 2 show that the greatest interest for participants was caused by a certain moment, a hero, an event, or an action presented in the text or comics. Also, most participants pay attention to the features of the narrative in the text (a way of expressing the author's thoughts, certain words). In addition, they are interested in showing their own emotions in the analysis of the comics. However, there is a significant percentage of the surveyed who found the observed texts and comic books boring, because they did not differ in novelty or originality of the plot. Moreover, when viewing/reading comic books and texts with high degrees of blurring, some participants admitted that these stimuli did not interest them because of the inability to disassemble anything (category "influence of external factors on perception").

Interrelations between individual parameters of perception of stimuli (with different degrees of blurring) with understanding were determined using the Spearman rank correlation coefficient (Brudnyy, 1975; Agafonov, 2006; Znakov, 2007).

\section{Conclusion}

In general, the following features of perception of visual stimuli by the subjects of different degrees of blurring can be noted:

1) When participants analyze texts and comics, it is common for them to fixate on what is important for understanding the details and characters of the presented plot.

2) When comprehending the comic books observed, the subjects are characterized by the selectivity of perception, which manifests itself in ignoring the intermediate results and transition to the final actions of the characters, which are key to understanding the entire plot of the image as a whole.
3) Participants differ in the level of volitional regulation of behavior: even when reading a blurry, difficult to comprehend text, they try to identify the main characters and use them to recreate the meaning of the text.

Acknowledgements The research was carried out within the framework of the funding of the research project Psychophysiological and NeuroLinguistic Aspects of the Verbal and Nonverbal Pattern Recognition Process, the project of the Russian Science Foundation No. 14-18-02135.

\section{Compliance with ethical standards}

Disclosure of potential conflicts of interest I have no conflicts of interest to disclose.

Research involving human participants and/or animals All procedures performed in studies involving human participants were in accordance with the 1964 Helsinki declaration and its later amendments.

This article does not contain any studies with animals performed by any of the authors.

Informed consent Informed consent was obtained from all individual participants included in the study.

\section{References}

Agafonov, A. Y. (2006). Cognitive psychomechanics of consciousness, or how consciousness unconsciously makes a decision about awareness. Samara, Russia: Univers grupp.

Bahtin, M. M. (1986). Aesthetics of verbal creativity. Moscow, Russia: Iskusstvo.

Bamberg, M. (2011). Who am I? Narration and its contribution to self and identity. Theory \& Psychology 21(1), 3-24.

Belobrykina, O. A. (2016). Features of emotional preschoolers development in modern conditions. Smalt, 1, 9-15.

Belobrykina, O. A., \& Vorobyova, P. S. (2015). Psychological descriptors of emotional competence of modern preschool children: Pedagogics. Psychology: Selected papers of the International Scientific School "Paradigma" (pp. 90-99). Yelm, WA: Science Book Publishing.

Bilynsky, Y. Y., Ratushny, P. M., Yukysh, S. V, Barylo, A. S., Amirgaliyev, Y., Kotyra, A., Burlibay, A., Morarenko, V. (2017). Contouring of microcapillary images based on sharpening to one pixel of boundary curves. Proceedings of SPIE - The International Society for Optical Engineering, 10445, Article number 104450Y.

Bodalev, A. A. (2012). The perception and understanding of human to human. Moscow, Russia: Kniga po Trebovaniyu.

Bransford, J. D., \& McCarroll, N. S. (1974). A sketch of cognitive approach to comprehension: Some thoughts about understanding what it means to comprehend. In D. S. Palermo (Ed.), Cognition and symbolic processes (pp. 189-229). Hillsdale, NJ: Erlbaum.

Brudnyy, A. A. (1975). Understanding as a philosophical and psychological problem. Questions of Psychology, 10, 109-117.

Brudnyy, A. A. (2002). Psychological hermeneutics. Moscow, Russia: Labirint.

Brudnyy A. A., Yakovlev A. A., \& Filatov V. P. (1991). Riddle of human understanding. Moscow, Russia: Politizdat.

Buyakas, T. M. (2009). Phenomenology of meaning: Meaning as the call of the soul. Moscow Psychotherapeutic Journal, 2, 94-109. 
Clark H. H. (1977). Inferences in comprehension. In S. J. Samuels \& D. LaBerge (Eds.), Basic processes in reading: Perceptions and comprehension (pp. 244-268). Hillsdale, NJ: Erlbaum.

Denham S. A. (2006). Social-emotional competence as support for school readiness: What is it and how do we assess it? Early Education and Development, 17, 57-89.

Doblayev, L. P. (1982). The semantic structure of the text and problems of its understanding. Moscow, Russia: Pedagogika.

Epshteyn, M. N. (2007). Life as a thesaurus. Consultative Psychology and Psychotherapy, 4, 47-56.

Gelmgolts, G. O., Maklakov, A. (2002). About perception in general: Cognitive mental processes. Saint-Petersburg, Russia: Piter.

Grossmann, A., \& Morlet, J. (1984). Decomposition of Hardy functions into square integrable wavelets of constant shape. SIAM Journal on Mathematical Analysis, 15(4), 723-736.

Gruschka, A. (2011). Verstehen lehren: Ein Plädoyer für guten Unterricht. Stuttgart, Germany: Reclam.

Keltner, D., \& Haidt, J. (1999). Social functions of emotions at four levels of analysis. Cognition and Emotion 13 (5), 505-521.

Kostyuk, G. S. (1959). Questions of psychology of thinking. Psychological science in the USSR (Vol. 1, pp. 357-440). Moscow, Russia: APN RSFSR.

Kostyuk, G. S. (1988). About psychology of understanding. Moscow, Russia: Pedagogika.

Kvasyuk, T. Y. (2010). Understanding as a psychological and pedagogical phenomenon. Knowledge. Understanding. Skill 1, 174-178.

Lamminpiya, M., Zaschirinskaia, O. V., \& Shelepin, Y. E (2015). Psychophysiological analysis of text reading and understanding. Human Physiology, 41(2), 130-134. Retrieved from: http://link. springer.com/article/10.1134/S0362119715020097

Leontyev, A. N. (2005). Activity, consciousness and personality. Moscow, Russia: Smysl Academia.

Levkova, L. Yu. (2009). Features of the processes of understanding, perception and thinking in connection with the problem of teaching students to read and understand the text. MGOU Messenger, 4, 91-94.

Lidin, K. L. (2004). Psychological mechanisms of the impact of the image on the emotional sphere of the person. Irkutsk, Russia: IGU.

Makarov, N. D. (2001). Content analysis (the method of quantitative study of the content of social information). Moscow, Russia: NMTsSPO.

Marr D. (1982). Vision. New York: W. H. Freeman and Co.

Matsumoto, D. (2003). Psychology and culture. Saint-Pitersburg, Russia: Piter.

Matyushkina, A. M. (1965). Psychology of thinking. Moscow, Russia: Progress.

Menchinskaya, N. A. (2004). Problems of training, education and mental development of the child. Moscow, Russia: MPSI.

Mey, R. (2001). Existential psychology. Moscow, Russia: Aprel Pres.

Myasishchev, V. N. (1995). Relationship psychology. Moscow, Russia: Institut prakticheskoy psihologii.

Nalchadzhyan, A. A. (2009). Psychological adaptation: Mechanisms and strategies. Moscow, Russia: Eksmo.

Pelc, K., Kornreich, C., Foisy, M. L., \& Dan, B. (2006). Recognition of emotional facial expressions in attention-deficit hyperactivity disorder. Pediatric Neurology, 35(2), 93-97.

Portnova, T. V. (2016). Practices and methods for actualization of the scientific information in art excursions (Excursions and cultural heritage in the contemporary world). International Journal of Environmental and Science Education, 11(14), 6690-6696.

Rehbein, B., Saalmann, G., \& Verstehen. (2009). Theorie und Methode. Konstanz, Germany: UVK Verlagsgesellschaft.

Rishar, Z. F. (1998). Mental activity: Understanding, reasoning, finding solutions. Moscow, Russia: Institut psikhologii RAN.

Rubinshteyn, S. L. (1958). About thinking and ways of research. Moscow, Russia: AN SSSR.

Rumelhart, D. E. (1977). Understanding and summarisation brief stories. In S. J. Samuels \& D. LaBerge (Eds.), Basic processes in reading: Perceptions and comprehension (pp. 265-303). Hillsdale, NJ: Erlbaum.

Saarni, C. (1999). The development of emotional competence. New York, NY: Guilford Press.

Shinysherova, G. B., Yessimov, B. K., Tuleubayev, Z., Seitbayev, K. Z., Sagyndukova, S. Z., Dyussekenova, A. B. (2018). Influence of training of cognitive - practical activity of students on efficiency of professional training in the process of educational field practice on biology. Periodico Tche Quimica, 15(30), 322-329.

Solso, R. (2006). Cognitive psychology. Saint-Petersburg, Russia: Piter.

Torndayk, E., \& Uotson, D. (1998). Behaviorism. Principles of learning based on psychology: Psychology as a science of behavior Moscow, Russia: AST-LTD.

Vygotskiy, L. S., \& Davydov, V. V. (1982). Problems of general psychology (Vol. 2). Moscow, Russia: Pedagogika.

Zashchirinskaia O. V., Khasnulina V. I., Chukhrovoy M. G., \& Belobrykinoy O. A. (2015a). Recognition of non-verbal patterns by juniors upon presentation of conventional gestures. Proceedings of the 4th International Symposium, Psychological and Pedagogical Technologies in Conditions of Innovative Processes in Medicine and Education. Novosibirsk, Russia: Nemo Press.

Zashchirinskaia, O. V., Belobrykina, O. A., \& Bolshunovoy, N. Y. (2015b). Emotional component of non-verbal communication. Proceedings of the International Symposium Psychology of Motivation: Past, Present, Future, dedicated to the 85th anniversary of the doctor of psychological sciences, honorary professor of the NGPU, V. G. Leontyev (pp. 156-163). Novosibirsk, Russia: Nemo.

Zhinkin, N. I. (1964). About coded transitions in internal speech. Questions of Linguistics, 6, 26-38.

Zinchenko V. P. (1997). Work of understanding. Psychological Science and Education, 3, 42-52.

Zinchenko, V. P. (1998). Psychological pedagogy. Samara, Russia: Samarskiy GPU.

Znakov V. V. (1991). Understanding as a problem of the psychology of thinking. Psychology, 1, 18-26.

Znakov V. V. (2002). Psychology of understanding and narrative psychology. Moscow, Russia: Smysl.

Znakov, V. V. (2007). Understanding in thinking, communication, human existence. Moscow, Russia: Institut Psikhologii.

Znakov, V. V. (2013). Understanding, comprehension and contemplation. Proceedings of the Russian Symposium Contemplation as a Modern Scientific-Theoretical and Applied Problem (pp. 43-60). Samara, Russia: PG SGA.

Publisher's note Springer Nature remains neutral with regard to jurisdictional claims in published maps and institutional affiliations. 